\title{
The Effect of Managerial Ability and Tone of Earnings Announcements towards Market Reactions
}

\author{
Zaenal Fanani ${ }^{*}$, Zakiyyah Riris Merbaka ${ }^{2}$ \\ 1,2 Accounting Department, Economic and Business Faculty, Universitas Airlangga \\ Л. Airlangga No.4, Surabaya, Indonesia \\ *Corresponding author; Email: fanani@feb.unair.ac.id
}

\begin{abstract}
This study aims to examine and analyse the effect of Managerial Ability, Tone of Earnings Announcements, and Market Reactions. Using Return on Asset and Firm Size as control variables. In this study population taken is manufacturing companies that are listed on the Indonesia Stock Exchange during the year 2015-2016. Based on the population criteria set, the sampling method is purposive sampling. The sample of this research is 99 firm year of 2015 and 91 firm-year in 2016. The final sample of this research is 190 objects. Independent variables in this research are managerial ability as a moderator variable, and the other of independent variable is tone of earnings announcement. The dependent variable in this research is market reaction which proxy with cumulative abnormal return $(-3,3)$. Data were collected using secondary data in the form of financial statements and annual reports. The analysis technique used is multiple linear regression. This research found there is influence between the tone of earnings announcement to market reaction, but there is no influence between managerial skill, tone of earnings announcement to market reaction.
\end{abstract}

Keywords: Managerial skill; tone of earnings announcement; market reaction.

\section{INTRODUCTION}

Stakeholders involved in the world of capital market need information for deciding their investment. The information needed is financial statements and annual report that has been published by the companies. Financial statements are said to be useful if the information contained in their components can spark reactions in the market. This market reaction is measured by using the value of changes in stock prices or by using abnormal return [11]. The concept explained by [3] said that the increase of stock trading reaction is an indicator of the information included in the financial statements, especially the information about earnings because investors believe that company that makes good earnings will show good prospects and will give optimal returns for the investors.

A good financial statements disclosure shows that the company have good managerial skills quality. [5] states his idea about managerial skills, which is a management skill in managing resources from input into an output that have a high selling value. Managing a company that have many resources, management with good managerial skills will optimize the output by using the input or the existing resource efficiently. Therefore, management with good managerial skills will maintain the company's value and maximize the performance compared to the management with bad managerial skills.
Toshiba's case in May 2015 is an example of bad managerial skills. Toshiba shocked the whole world when they stated that their company was investigating an internal accounting scandal and had to make a revised earnings calculation from the last 3 years. They made various efforts in order to make their earnings to be different from what it actually was. This shows the non-existence of good financial statements even though the position and function of financial statements are actually very important, and that is why the reasonableness of the information that is included inside becomes something that is absolute and can be used to evaluate the company's managerial performance. This is applied so that every user of the financial statements can get accurate information and not the misleading one, which can be used as a step of decision making in investment.

According to [14], they predict that good managerial skills can be passed by reviewing the tone of earnings announcement information that is announced by issuer company in the form of financial statements and annual reports so that it can make potential investors react in response to the stock price developments.

Research [1], [4], [7], [9], and [17] find that the tone related to company's disclosure is in the form of profitability and management incentives. This research explores the tone deciding criterion, managerial skills, which is defined as a form of efficiency 
from the managerial skills towards industries skills to change company's resources into earnings [5]. A capable manager is a manager who has skills in decision making and its application that can deliver the company to higher efficiency of managerial skills and tone of earnings announcement information and make investors respond the market with taking a decision to buy or sell the existing stocks. This is related to the phenomenon of "buy on rumours, sell on news". The stock price will have already been discounted when there is newly published information, so when there is good published news, the stock price will likely to fall. One of the possible cause of this situation is the existence of some people who make use of the previous rumour to predict the earnings rate that will be published (or it can be because they have private information) and they do make a profit when the news is already published.

The introduction that has been explained above brings confidence to the author in the form of research motivation, that is: this research replicates and modifies the research of [14] because that research combines managerial skills, tone of earnings announcement variable, and observes the effect to market responses. That research is a new thing in Indonesia

This research is motivated by the limited study in Indonesia that is related to stock's price relation and readability of accounting reports, especially those that discuss the positive tone and negative tone that are found from the research of [13] so it needs to be researched, especially on the companies in Indonesia. That research needs to be developed and it can be done by taking samples from manufactures companies that are registered in Indonesia Stock Exchange on 2015-2016 to help investors see the investment opportunities listed in capital market reaction in Indonesia. It can happen because the manufacturer companies in Indonesia Stock Exchange (IDX) have more activities when doing their operational activities.

\section{Signalling Theory}

The information given in the signalling theory is a signal from the companies' management that describes the companies' condition to related parties such as owners. Circulated information provides a signal that could influence investors in deciding their investment. Investors' acts are reflected in the stock prices movement and the trading volume around the time the information is released.

The form of information that is released by the companies that are used as a signal by the companies' external parties is the annual report that could be accounting information, information related to financial reports, or information that is not related with financial reports. The signal that the company management provides in the form of financial reports that serves the result of owner's desire realization and information regarding accounts in financial reports that are important for investors and potential investors. The information revealed by companies' managements is a signal that becomes a clue for the investors on the future prospects of the companies [3].

\section{Hypothesis Development}

\section{Tone of Earnings Announcements on Market Reaction}

The first hypothesis is based on the findings of previous research that show positive reactions from the stock market after analyzing the tone of earnings announcements [4]. The research of [4] and [6] find that the tone of earnings announcements makes the market to react positively to the tone revealed in companies' earnings and supported by the companies' characteristics. [4] and [8] documented the direct effects of earnings announcements' tone on the investors about the companies' operational performance that shows that the abnormal return cumulative $(-3,3)$ in the day of earnings announcements increases, which can be seen from the positive tone of earnings announcements. The tone of earnings announcements gives information for market players and thus could influence the stock price [19]. The tone that is used by the market has significant influences on the market reaction, which shows that the optimistic company's report indicates good earnings announcements [19]. This empirical evidence shows that market players need to consider the tone of earnings announcements. If this assumption states that there is an unusual signal, the market will not respond differently towards the tone of earnings management released by the companies [14]. Thus, the hypothesis of this research is:

$\mathrm{H}_{1}=$ Tone of earnings announcements has positive influences on market reaction

\section{Managerial Skills Strengthen the Tone of Earnings Announcements on Market Reaction}

Managerial skill is a manager's skills in operating the company effectively and efficiently. Managerial skill represents the manager's efficiency level in managing company resources to create output. A manager that is more skilful and professional than a manager is less capable in understanding technology and industry trends, predicting product demands, investing in high-value projects, managing employees, and successfully identifying 
investment opportunities. A management team with high-efficiency level can help its company in achieving better operational performance, provide better company information, and create high-quality financial reports [5].

The research of [4] and [14] find that a company's managerial skill influences the emergence of tone of earnings announcements towards market reaction and good managerial skills supported by the company's characteristics. [8]. Based on the research of [19], which explains that an unexpected improvement in positive tone (for example, praising the company's performance) influences the increase of stock price and market reaction, which improves the result of the next sales and equity sales.

The previous explanation predicts that managerial skill moderates or strengthens the tone of earnings announcement on market reaction, and thus the following hypothesis emerges:

$\mathrm{H}_{2}=$ Managerial skill strengthens the tone of earnings announcements towards market reaction.

\section{RESEARCH METHOD}

This research uses a quantitative approach. This research is a quantitative one because this research is structured and uses generalized data.

\section{Operational Variable Definition and Mea- surement}

The independent variables that double as moderator variables in this research are managerial skills (MA_R) and tone of earnings announcements (TONE). The dependent variable in this research is the market reaction that is proxied with Cumulative Abnormal Return (CAR) (-3, 3). The control variables of this research are Return on Assets (ROA) and Firm Size (SIZE).

\section{Managerial Skill}

Managerial skill is a management efficiency level in operating a company's resources [5]. Managerial skill is measured in two steps. The first step is finding the company's efficiency value that includes net PPE, net research and development, goodwill, intangible asset, cost of goods sold, and SG\&A (selling, general, and administrative expense) as the inputs and sales as the output to create residual value. Net PPE, net research and development $(\mathrm{RnD})$, goodwill, and intangible asset are measured in the beginning of the year ( $\mathrm{t}-1)$ while the cost of goods sold and SG\&A are measured at the end of the year ( $t)$. The first step of company efficiency is measured with Stochastic Frontier Analysis (SFA) method by using Fixed Effect Model
(FEM) regression model and using Eviews software. Residual value is acquired from the processing result. The efficiency value is calculated from 1 $\mid$ Residual $\mid$. The formula used to calculate a company's efficiency is as follows:

Sales $_{i t}=\alpha+\beta_{1} P P E_{i t}+\beta_{2} R n D_{i t}+\beta_{3}$ Goodwillit + $\beta_{4} I A_{i t}+\beta_{5} C O G S_{i t}+\beta_{6} S G \& A_{i t}+e_{i t}$

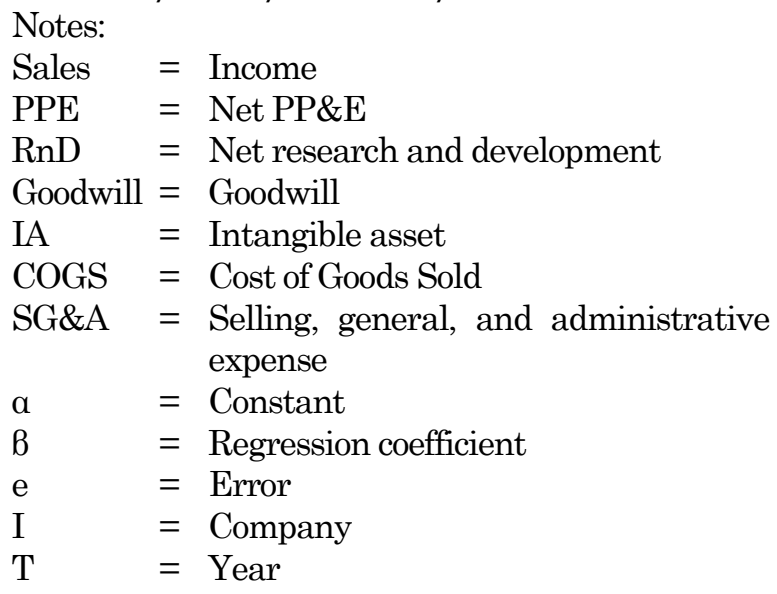

The independent variables that double as moderator variables are tested through two steps to ensure that the efficiency value of the first step can describe rigid managerial skills. On the first-test the efficiency value is able to describe managerial skills but need the validation that the efficiency value is really rigid on the managerial skills owned by the company and is not influenced by the company's characteristics such as total asset, market share, free cash flow, and firm age, and thus the second test is done, the efficiency value from the previous step as dependent variable is processed with four company's characteristics and total asset, market share, free cash flow, and firm age as free variables. Total asset is measured through the total assets owned by the companies. Market share is measured by multiplying floating stocks with the stock price. Free cash flow is measured with the dummy variable, 0 , when the free cash flow is negative, and 1 when the free cash flow is positive. Firm age is measured with the company's Initial Public Offering (IPO). Below is the formula used to calculate managerial skills in the second step:

$F E_{i t}=a+\beta_{1} T A_{i t}+\beta_{2} M S_{i t}+\beta_{3} F C F_{i t}+\beta_{4} A G E_{i t}+e_{i t}$

Notes:

$\mathrm{FE}=$ Firm efficiency

$\mathrm{TA}=$ Total asset

$\mathrm{Ms}=$ Market share

$\mathrm{FCF}=$ Free Cash flow

Age $=$ Firm age

$\mathrm{a}=$ Constant

B = Regression coefficient

$\mathrm{e} \quad=$ Error

$\mathrm{i}=$ Company

$\mathrm{t} \quad=$ Year 


\section{Tone of Earnings Announcements}

Tone is a company's communication language that is learned through the proportion of positive and negative words. Textual analysis, document's content checking, becomes more common in accounting and financial research [12]. Weighting scheme decides the weight for each positive and negative words that are identified from certain disclosures. The most common weighting scheme is equal weight, where every appearance of diction in the word list has the same weight. For example, a 2000 words document which contains 125 positive words and 75 negative words receives a tone score of $(125-75) /(125+75)=0,4$. The two alternative word lists and weighting scheme [8]. This research calculates tone with the following formula:

TONE (Tone of earnings announcements) =

$\underline{100 *(\text { positif word count-negative word count) }}$ total word count

\section{Market Reaction}

Market reaction is the return produced by securities in a period of time that is different from the expected return [11]. The proxy of market reaction in this research is abnormal return. The window period that is used to calculate abnormal return is 7 days involving, 3 days after and before, and 1 day when each company's financial report is published. The three days of window period before the date of the announcement is used to anticipate the possibility of some investors knowing the information before its announcement (information leak). To test the abnormal return value for 7 days, the AR is being accumulated (CAR). The calculation of CAR (Cumulative Abnormal Return) for each company is the accumulation of the average of abnormal return in the 7 days of windows period by using the following formula:

$$
C A R_{i}=\sum_{a=t-3}^{3} A R_{i, a}
$$

Notes:

$\mathrm{AR}=$ Abnormal return for the i securities on the $a$-th day, starting from t1 (the first day of window period) until the $t$ day

CARi $=$ Accumulation of $i$ stock's abnormal returns from the first day of the observation period $(t=-3)$ until the third day.

\section{Control Variable}

In the previous research, there are several variables that influence the tone of earnings announcements towards market reaction. This research tries to avoid any research bias, thus, this research uses control variables such as ROA and Size. [10] defines ROA as a ratio that is used to calculate the net profit received from the use of assets. This ratio is formulated by:

Return on Assets $(R O A)=\frac{\text { Laba bersih }}{\text { Total Aktiva }} \times 100 \%$

Meanwhile, firm size is the number and variation of production capacity and skills that the companies have or the number and variation of services that the companies can give simultaneously to their customers [16].

SIZE $=$ Ln Total Assets

\section{Data Sources and Types}

The data type used in this research is secondary data, data that are received from sources related to the research. This research uses secondary data in the form of the annual financial report of manufacture companies listed in IDX on 20152016. The data is gathered from IDX's website, www.idx.co.id, and yahoo finance.

\section{Population and Sample}

The population used in this research is all manufacturing companies listed in Indonesia Stock Exchange (IDX) from 2015-2016. There are 190 companies' data that fulfil the research criteria.

\section{Analysis Model}

This research uses multiple linear regression model and moderation model as its analysis tools. This hypothesis is done by using SPSS 22 . The hypothesis test that uses the linear regression model or model 1 can be formulated as:

$C A R_{i t}=a_{+} B_{1}$ Tone $_{i t}+B_{2} \mathrm{ROA}_{i t}+B_{3} \mathrm{SIZE}_{i t}+\mathrm{e}_{i t}$

Notes:

TONE $=$ Tone of earnings announcements

ROA $=$ Return on Assets

SIZE $=$ Firm Size

$\mathrm{a} \quad=$ Constant

$B=$ Regression coefficient

$\mathrm{e} \quad=$ Error

$\mathrm{i} \quad=$ Company

$\mathrm{t} \quad=$ year

Meanwhile, the moderation model or hypothesis 2 test model is formulated with the Model 2 as follows:

CAR $(-3,3){ }_{i t}=\alpha+B_{1} \mathrm{TONE}_{\mathrm{it}}+B_{2} \mathrm{MA} \_R_{\mathrm{it}}+B_{3} \mathrm{TONE}_{\mathrm{it}}{ }^{*}$ $\mathrm{MAR}_{\mathrm{it}}+\mathrm{B}_{4} \mathrm{ROA}_{\mathrm{it}}+\mathrm{B}_{5} \mathrm{SIZE}_{\mathrm{Sit}}+\mathrm{e}_{\mathrm{it}}$

Notes:

$\mathrm{CAR}=$ Market Reaction

TONE = Tone of Earnings Announcements

TONE *MA_R = Interaction between managerial skill and the tone of earnings announcements 


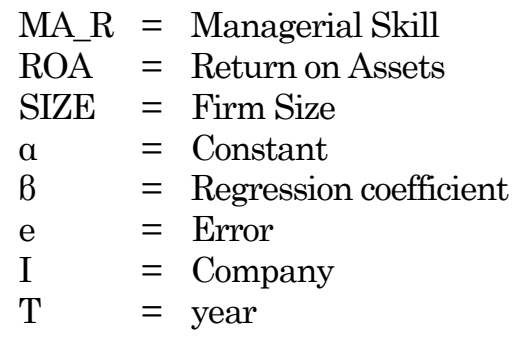

\section{RESULTS AND DISCUSSION}

\section{Descriptive Analysis}

The descriptive statistic gives the image or description of the variables used in this research by showing the mean, median, modus, and standard deviation of each variable.

Table 1. Descriptive Statistics

\begin{tabular}{lrrrrr}
\hline Variable & N & $\begin{array}{l}\text { Mini- } \\
\text { mum }\end{array}$ & $\begin{array}{c}\text { Maxi- } \\
\text { mum }\end{array}$ & Mean & $\begin{array}{c}\text { Std. } \\
\text { Deviation }\end{array}$ \\
\hline MA_R & 190 & $-0,3003$ & 0,1376 & 0,000000 & 0,0930574 \\
TONE & 190 & $-98,4375$ & 100,0000 & $-34,930898$ & 45,3535695 \\
CAR & 190 & $-0,1651$ & 0,1488 & $-0,003376$ & 0,0554105 \\
ROA & 190 & $-0,1845$ & 0,4316 & 0,044226 & 0,0876739 \\
SIZE & 190 & 24,4170 & 33,1988 & 28,559407 & 1,6410668 \\
TONExMA_R & 190 & $-17,2893$ & 15,6659 & $-0,954346$ & 4,9479001 \\
\hline
\end{tabular}

\section{Analysis of Classical Assumption Test Result}

\section{Normality Test}

Normality test is used to examine whether the dependent and independent variables in the regression model have normal distribution or not. In this research, the normal distribution assumption can be fulfilled after transforming the CAR variable, cumulative abnormal return, into a natural logarithm. Based on model 1 and model 2's P-P plot, the research data is located around and along the direction of the diagonal line. Thus, it can be concluded that model 1 and 2 have fulfilled the assumption of normality.

\section{Multicollinearity Test}

The result of model 1's multicollinearity test shows that the tolerance values of TONE, ROA, and SIZE are 0.997; 0.969; and 0,968 respectively. The TONE, ROA, and SIZE variables have more than 0,10 tolerance value. The VIF value of TONE is 1,003; ROA 1,032; and SIZE 1,033, all three have VIF value less than 10 . These results show that there is no multicollinearity problem. Meanwhile, model 2 shows the tolerance value of TONE, MA_R, TONExMAR, ROA, and Size as 0,901; 0,745; 0,774; 0,$967 ; 0,958$ each, which are all more than 0,10 . So is their VIF value where TONE has the value of 1,110; MA_R 1,343; TONExMA_R 1,292; ROA 1,034; and SIZE 1,044, all of them less than 10.

\section{Heteroscedasticity Test}

From the heteroscedasticity test, it is found that there is no heteroscedasticity on model 1 and 2 because the dots in the scatter plot are scattered and not forming patterns.

\section{Autocorrelation Test}

The result of the autocorrelation test on model 1 shows that the Durbin Watson value of model 1 is 2,059 , which is located between the upper limit (du) of 1,759 and the lower limit (dl) of 2,205, thus, there is no autocorrelation. Meanwhile, the Durbin Watson value of model 2 is 2,088, located between the upper limit (du) of 1,806 and lower limit (dl) of 2,194 , thus, there is no autocorrelation.

\section{Hypothesis Verification}

Table 2. Regression Model 1 Result

\begin{tabular}{|c|c|c|c|c|}
\hline \multirow{2}{*}{ Variabel } & \multicolumn{3}{|c|}{ Multiple Linear Regression } & \multirow[t]{2}{*}{ Conclusion } \\
\hline & B & 7 & Sig. & \\
\hline Constant & 0,0030 & 0,390 & 0,969 & Non-Significant \\
\hline TONE & 0,0002 & 1,970 & 0,050 & Significant \\
\hline ROA & $-0,0010$ & $-0,012$ & 0,990 & Non-Significant \\
\hline SIZE & $-0,000002$ & $-0,001$ & 1,000 & Non-Significant \\
\hline $\mathrm{R}$ & 0,143 & & & \\
\hline $\mathrm{R}^{2}$ & 0,021 & & & \\
\hline Total & 190 & & & \\
\hline
\end{tabular}

Based on the result of multiple linear regression calculation, the regression equation (Model 1) can be formulated as:

$C A R=0,0030+0,0002 T O N E+-0,001 R O A+$ $0,000002 S I Z E$

The hypothesis verification is done by observing the $t$-test that has the goal to find the influence of independent variables on the dependent variable partially. Based on the summary results of the multiple linear regression analysis, the regression coefficient shows varied results: positives and negatives. Positive coefficient shows similar changes between independent variables on dependent variable, while the negative coefficient shows different directions of changes between independent variable toward the dependent variable. Below is the result of the multiple linear regression model hypothesis tests:

The value of t-test on the tone managerial skill variable (TONE) is 1,970 with a significance level of 0,050 , which lower than the significance level of $10 \%$ or 0,10 , and thus, $\mathrm{H} 0$ is rejected and $\mathrm{H} 1$ is accepted. With that, it can be concluded that the tone of earnings announcements positively and significantly influences the market reaction. 
The value of t-test on the Return on Assets (ROA) control variable is -0,012 with a significance level of 0,990, which is higher from 0,10 and thus, $\mathrm{H} 0$ is accepted and $\mathrm{H} 1$ is rejected. With that, it can be concluded that Return on Assets (ROA) does not have a significant influence on the market reaction.

The value of t-test on firm size (SIZE) control variable is $-0,001$ with a significance level of 1,000 , which is higher than the significance level of 0,10 and thus, $\mathrm{H} 0$ is accepted and $\mathrm{H} 1$ is rejected. With that, it can be concluded that firm size (SIZE) does not have a significant influence on the market reaction or cumulative abnormal return. This happens because there are differences in the research objects, where the previous research is done to companies that are listed on the Shanghai Stock Exchange on the 2007-2012 period.

The regression model analysis shows that the tone of earnings announcements variable positively and significantly influences the market reaction. It means that the higher the tone of earnings announcements, the better the market reaction. Meanwhile, the return on assets and firm size variables does not have a significant influence on the market reaction.

The coefficient of determination (R-Square) shows how much the independent variables describe the dependent variable. The statistical calculation result of the multiple linear regression (Table 2 model 1) shows an $R$ square value of 0,021 . It means that tone of earnings announcements (TONE), return on assets (ROA), and firm size (SIZE) are able to explain $2,1 \%$ of the cumulative abnormal return while the other $97,9 \%$ is influenced by other variables that are not included in the research model.

Table 3. Regression Model 2 Result

\begin{tabular}{|c|c|c|c|c|}
\hline \multirow{2}{*}{ Variable } & \multicolumn{3}{|c|}{ Multiple Linear Regression } & \multirow[t]{2}{*}{ Conclusion } \\
\hline & $\mathrm{B}$ & $\mathrm{T}$ & Sig. & \\
\hline Constant & -0.007 & $-0,105$ & 0,917 & Non-Significant \\
\hline TONE & 0,0002 & 1,919 & 0,057 & Significant \\
\hline MA_R & $-0,016$ & $-0,322$ & 0,748 & Non-Significant \\
\hline TONE*MA_R & 0,001 & 1,258 & 0,210 & Non-Significant \\
\hline $\mathrm{ROA}$ & $-0,002$ & $-0,034$ & 0,973 & Non-Significant \\
\hline SIZE & 0,0004 & 0,161 & 0.872 & Non-Significant \\
\hline $\mathrm{R}$ & 0,185 & & & \\
\hline $\mathrm{R}^{2}$ & 0,034 & & & \\
\hline
\end{tabular}

The interpretation of the moderated regression test result is: The value of t-test on the tone of earnings announcements (TONE) variable is 1,919 with a significance level of 0,057 . This significance level is lower than 0,10 and thus H0 is rejected and $\mathrm{H} 1$ is accepted. It can be concluded that tone of earnings announcements has positive and significant influences on the market reaction or cumulative abnormal return (CAR).

The value of t-test on the managerial skill (MA_R) variable is 0,322 with a significance level of
0,748 . This significance level is higher than 0,10 and thus it can be concluded that managerial skill does not significantly influence market reaction.

The value of t-test on the tone of earnings announcements (TONE) with managerial skill (MA_R) variable is 1,258 with a significance level of 0,210 . This significance level is higher than 0,10 . It means that managerial skill does not moderate the tone of earnings announcements on market reaction. Or that managerial skill does not strengthen or influence the tone of earnings announcements on market reaction.

The value of t-test on the return on assets (ROA) variable is -0,034 with a significance level of 0,973 , which is higher than 0,10 and thus HO is accepted and $\mathrm{H} 1$ is rejected. Thus, it can be concluded that Return on Assets (ROA) does not significantly influence the market reaction.

The value of $t$-test on the firm size (SIZE) variable is 0,161 with significance level of 0,872 . This significance level is higher than 0,10 which is higher than 0,10 and thus $\mathrm{H} 0$ is accepted and $\mathrm{H} 1$ is rejected. Thus, it can be concluded that firm size (SIZE) does not significantly influence the market reaction.

Based on the Table of regression model analysis result, the tone of earnings announcements, managerial skill, the interaction between tone of earnings announcements and managerial skill, return on assets, and firm size variables do not have significant influence on market reaction

Managerial skill does not strengthen the tone of earnings announcements variable influence on market reaction while moderating it. The regression coefficient of the interaction between the tone of earnings announcements and managerial skill variable is not significant. This means that managerial skill does not have influence on market reaction.

The coefficient of determination (R-Square) shows how much the independent variables describe their dependent variable. The statistical calculation result of the moderated regression (Table 3 model 2) shows an $R$ square value of 0,034 . It means that tone of earnings announcements (TONE), managerial skills (MA_R), interaction between tone of earnings announcements and managerial skill (TONE*MA_R), return on assets (ROA), and firm size (SIZE) are able to explain $3,4 \%$ of the market reaction, while the other $96,6 \%$ is influenced by other variables that are not included in the research model.

\section{Tone of Earnings announcements on Market Reaction}

Based on the research result, it is known that the tone of earnings announcements has positive and significant influences on market reaction. This 
shows that the higher the tone of earnings announcements, the better the market reaction. A good market reaction is a signal for a good stock trading price quality and will attract investors' interests.

This research result is in accordance with the research of [4], [6], and [14] which tested the tone of earnings announcements and found that the market reacts positively towards the tone that is expressed in earnings announcements. This research interprets the results of previous research by testing the influence of the management teams' skill towards the tone of earnings announcements and its influence on market reaction based on the tone at the time of earnings announcements. The relationship between the changes in earnings announcements' tone on the research of [19] is proven to be able to influence market reaction because earnings announcements bring information to the capital market.

Managerial Skills Strengthen the Tone of Earnings Announcements on Market Reaction

Based on the test result, it is known that managerial skill does not moderate the tone of earnings announcements towards market reaction. This shows that there is no significant relationship between managerial skill, tone of earnings announcements with market reaction. Based on the test result, this research does not show that the amount of managerial skill has a significant role in moderating the influence of tone on market reaction. The result of this research explains that the level of managerial skill that is measured through its efficiency value in managing companies' resources does not strengthen the tone of earnings announcements. The requirements that have to be fulfilled so that the management can always be honest in carrying out their jobs are: pay attention to organizational culture, support the ethical decision making, and have a source of motivation to keep on doing things honestly.

\section{CONCLUSION}

Based on the analysis and research results explained in the previous chapters, it can be concluded that: Tone of earnings announcements has positive and significant influences on market reaction. This shows that the higher the tone of earnings announcements, the better the market reaction. The result of this research is in accordance with the research of [14] that finds that the tone of earnings announcements influences market reaction. The empirical evidence that supports the previous research done by [2] explains that earnings announcements bring information to the capital market. Managerial skill does not moderate the tone of earnings announcements towards market reaction. This shows that a higher level of managerial skill will still not strengthen the tone of earnings announcement on market reaction. The control variables, Return on Assets (ROA) and firm size (SIZE) does not significantly influence the market reaction.

\section{Limitation and Suggestion}

There are some possible limitations and shortcomings in this research, some of them are: (1) This research only uses manufacturing companies that are listed in IDX as research samples, (2) The research period is only two years, thus it does not rule out the possibility that the companies' performances are not reflecting the actual condition, (3) This research only tested some of the positive and negative tones from the worklist that refers to the research of [12], thus the meaning of the words with positive and negative tones in that research is hard to be defined correctly.

\section{REFERENCES}

[1] Arslan-Ayaydin, Ö., Boudt, K., and Thewissen, J. (2016). Managers set the tone: Equity incentives and the tone of earnings press releases. Journal of Banking and Finance, 72, 132-147.

[2] Ball, R., and Brown, P. (1968). An empirical evaluation of accounting income numbers. Journal of Accounting Research, 159-178.

[3] Brigham, E. F., and Houston, J. F., Manajemen Keuangan, edisi 8, Buku 1., Jakarta, 2001.

[4] Davis, A. K., Ge, W., Matsumoto, D., and Zhang, J. L. (2015). The effect of managerspecific optimism on the tone of earnings conference calls. Review of Accounting Studies, 20(2), 639-673.

[5] Demerjian, P., Lev, B., and McVay, S. (2012). Quantifying managerial ability: A new measure and validity tests. Management science, 58(7), 1229-1248.

[6] Demers, E., and Vega, C. (2014). Understanding the role of managerial optimism and uncertainty in the price formation process: evidence from the textual content of earnings announcements. Working Paper. www.ssrn. com

[7] Frankel, R., Mayew, W. J., and Sun, Y. (2010). Do pennies matter? Investor relations consequences of small negative earnings surprises. Review of Accounting Studies, 15(1), 220-242.

[8] Henry, E., and Leone, A. J. (2015). Measuring qualitative information in capital markets research: Comparison of alternative methodologies to measure disclosure tone. The Accounting Review, 91(1), 153-178. 
[9] Huang, X., Teoh, S. H., and Zhang, Y. (2013). Tone management. The Accounting Review, 89(3), 1083-1113.

[10] Lestari, M.I, and Sugiharto, T. (2007). Kinerja Bank Devisa dan Bank Non Devisa dan Faktor-Faktor Yang Memengaruhinya. Proceeding PESAT.

[11] Jogiyanto, H. M., Teori portofolio dan analisis investasi, BPFE. Yogyakarta, 2003.

[12] Loughran, T., and McDonald, B. (2011). When is a liability not a liability? Textual analysis, dictionaries, and 10-Ks. The Journal of Finance, 66(1), 35-65.

[13] Loughran, T., and McDonald, B. (2015). The use of word lists in textual analysis. Journal of Behavioral Finance, 16(1), 1-11.

[14] Luo, Y., and Zhou, L. (2017). Managerial ability, tone of earnings announcements, and market reaction. Asian Review of Accounting, 25(4), 454-471.
[15] Naim, M. (2000). Fads and fashion in economic reforms: Washington Consensus or Washington Confusion? Third World Quarterly, 21(3), 505-528.

[16] Niresh, A., and Thirunavukkarasu, V. (2014). Firm size and profitability: A study of listed manufacturing firms in Sri Lanka. International Journal of Business and Management, 9(4).

[17] Price, S. M., Doran, J. S., Peterson, D. R., and Bliss, B. A. (2012). Earnings conference calls and stock returns: The incremental informativeness of textual tone. Journal of Banking and Finance, 36(4), 992-1011.

[18] Spence, M. (1978). Job market signaling Uncertainty in Economics. The Quarterly Journal of Economics, 281-306.

[19] Tama-Sweet, I. (2014). Changes in earnings announcement tone and insider sales. Advances in Accounting, 30(2), 276-282. 